\title{
PENERAPAN MODEL PEMBELAJARAN ROLE PLAY TERHADAP KEMAMPUAN BERBICARA DALAM MEMERANKAN DRAMA PADA SISWA KELAS V SD NEGERI 68 SEBERANG ULU 1 PALEMBANG
}

\author{
Ice Nofrianti \\ SD Negeri 68 Seberang Ulu 1 Palembang \\ kbmuazzam@gmail.com
}

\begin{abstract}
Abstrak
Penelitian ini yaitu siswa kelas V SD Negeri 68 Seberang Ulu 1 Palembang yang berjumlah 30 orang. Berdasarkan analisis data obesrvasi pada siklus I jumlah keseluruhan kemampuan berbicara dalam bentuk memerankan tokoh drama melalui metode bermain peran siswa kelas $\mathrm{V}$ SDNegeri 68 Seberang Ulu 1 Palembang hanya $71.07 \%$ dan hanya ada 7 siswa mencapai KKM 70 atau $23.33 \%$. Sebaliknya, pada siklus II nilai sebesar $81.87 \%$ telah memenuhi standar ketuntasan klasikal. Kriteria keberhasilan siswa dalam memerankan tokoh drama, artinya pembelajaran berbicara dalam bentuk memerankan tokoh drama melalui metode bermain peran pada siklus II telah berhasil atau dinyatakan memenuhi kriteria yang telah ditetapkan. Berdasarkan hasil penelitian disimpulkan bahwa terdapat peningkatan kemampuan berbicara dalam bentuk memerankan tokoh drama melalui metode bermain peran (role play) pada siswa kelas $\mathrm{V}$ SD Negeri 68 Seberang Ulu 1 Palembang.
\end{abstract}

Kata Kunci: Berbicara, Memerankan Drama, Role Play

\begin{abstract}
The method of this research is classroom action research method (PTK). The sample in this research is the students of class V SD Negeri 68 Seberang Ulu 1 Palembang which amounts to 30 people. Based on the analysis of observation data in cycle I, the total speaking ability in the form of role plays through the role play method of $V$ class students SD Negeri 68 Seberang Ulu 1 Palembang only $71.07 \%$ and only 7 students reached KKM 70 or $23.33 \%$. In contrast, in cycle II the value of $81.87 \%$ has met the standard of classical mastery. The criterion of the students' success in playing the role of drama, meaning that learning to speak in the form of role plays through role play method on cycle II has succeeded or has fulfilled the criteria. Based on the result of the research, it is concluded that there is an increase of speech ability in the form of role plays through role play method on grade V students of SD Negeri 68 Seberang Ulu 1 Palembang.
\end{abstract}

Keyword: Speaking, Action Drama, Role Play 


\section{PENDAHULUAN}

Dunia pendidikan pada saat ini dituntut untuk senantiasa melakukan inovasi dalam pembelajaran, diberbagai aspek, mulai dari visi, misi, tujuan, program, layanan, model, teknologi, proses, sampai evaluasi. Selain itu juga pendidikan di Indonesia haruslah memiliki tujuan, salah satu tujuan tersebut adalah untuk meningkatkan kwalitas sumber daya manusia, sehingga sumber daya manusia dapat dapat bertambah dan juga sebagai asset yang sangat berharga dalam bidang pendidikan. Di dunia pendidikan juga kemampuan sumber daya manusia sangatlah dibutuhkan untuk mencapai suatu tujuan yang mencerminkan keberhasilan dari proses pembelajarn. Oleh sebab itu, pendidkan merupakan ujung tombak keberhasilan sumber daya manusia agar kwaitas di pendidikan di dunia semakin berkembang dan mampu bersaing dengan Negaranegara tetangga.

Salah satu bentuk penjaminan mutu pendidikan dapat berupa pembinaan terhadap kemampuan berbahasa. Semakin bertambah tinggi kebudayaan bangsa, semakin maju bahasannya.

Senada dengan hal tersebut, Dawson (dikutip Tarigan, 2008:1) menjelaskan bahwa bahasa seseorang mencerminkan pikirannya. Semakin terampil seseorang berbahasa, semakin cerah dan jelas pula jalan pikirannya..

Akan tetapi, pengembangan kemampuan berbicara tersebut belum dilaksanakan secara maksimal. Proses pembelajaran di kelas yang tidak relevan dengan yang diharapkan, mengakibatkan kemampuan berbicara siswa menjadi rendah. Seharusnya, untuk mengetahui pengembangan potensi/kemampuan/keterampilan berbicara siswa diperlukan serangkaian tes keterampilan berbicara dan pengamatan proses belajar mengajar yang cukup panjang.

Berdasarkan penejelasan di atas, peneliti melakukan observasi ke sekolah dan peneliti menemukan masalah dalam proses pembelajaran terutama dalam memerankan drama yang mana proses pembelajaran tersebut dilakukan secara konvensional (teknik pengajaran yang umumnya sering digunakan). Dengan 
demikian, dapat dikatakan bahwa kemampuan berbicara, khususnya materi memerankan tokoh drama dengan lafal, intonasi, dan ekspresi siswa kelas $\mathrm{V}$ SDN 68 Seberang I Ulu Palembang masih belum memenuhi Kriteria Ketuntasan Minimal (KKM). Adapun KKM yang harus dicapai siswa untuk materi memerankan tokoh drama pada tahun 2016/2017 sebesar 75 . Oleh sebab itu, dalam hal ini peneliti menggunakan "Role Play terhadap kemampuan memerankan drama pada siswa kelas V SD Negeri 68 Seberang I ulu Palembang" karena dengan model role play diharapkan dapat membuat siswa lebih aktif dan kreatif lagi dalam memerankan drama atau memahami pelajaran yang diberikan oleh guru dibandingkan dengan model konvensional.

\section{METODE PENELITIAN}

Model penelitian ini yang digunakan adalah Penelitian Tindakan Kelas. Menurut Arikunto (2014:16) penelitian tindakan kelas meliputi (1) perencanaan, (2) pelaksanaan, (3) observasi, dan (4) evaluasi dan refleksi. Penlitian tindakan kelas ini melibatkan guru yang mengajar bahasa Indonesia di kelas $V$ sebagai teman sejawat selama berlangsungnya penelitian.

Posedur dalam penelitian ini dilaksanakan mengacu pada rencana pembelajaran yang telah dibuat. Pembelajaran yang dilakukan bersifat fleksibel, dengan kata lain dapat berubah sesuai dengan kondisi yang ada dalam kegiatan pembelajaran. Guru mengajar dengan menggunakan RPP yang telah dibuat sedangkan peneliti mengamati dengan mengikuti pedoman observasi yang telah dibuat pada tahap perencanaan

\section{POPULASI dan SUBJEK PENILITIAN}

Dalam hal ini, peneliti mengambil sebuah sekolah untuk menjadi satu populasi yaitu pada SD Negeri 68 Seberang Ulu 1 Palembang yang terdiri beberapa kelas dan tergambar pada tabel berikut: 


\section{TABEL}

POPULASI

\begin{tabular}{|c|c|c|}
\hline $\begin{array}{c}\text { N } \\
0\end{array}$ & Kelas & Jumlah \\
\hline 1 & VA & 30 \\
\hline 2 & VB & 30 \\
\hline 3 & VC & 32 \\
\hline & Jumlah & 92 \\
\hline
\end{tabular}

Sampel adalah bagian dari populasi dan karakteristik yang dimiliki oleh populasi. Subjek penelitian ini adalah siswa kelas V SD Negeri 68 Seberang Ulu 1 Palembang dengan jumlah 30 orang, dipilihnya siswa kelas $V$ dengan jumlah 30 orang dikarenakan kemampuan berbicara khususnya dalam memerankan drama masih kurang mampu.

\section{HASIL PENELITIAN DAN PEMBAHASAN}

\section{Silklus I}

Pada siklus 1 ini, peneliti mengemukakan bahwa siklus 1 merupakan pembelakuan pertama dalam penelitian menggunakan model pembelajaran role play. Siklus pertama ini juga merupakan bagian dari perencanaan dan tindakan yang disusun peneliti bersama teman sejawat yaitu guru bahasa yang mengajar pelajaran bahasa Indonesia yaitu ibu $\mathrm{Hj}$. Meilliana. Pada kegiatan ini peneliti merencanakan beberapa kegiatan yaitu (1) menyiapkan perangkat pembelajaran (RPP) tentang bermain peran, (2) menentukan indicator pembelajaran, (3) membuat lembar penelitian siswa yakni instrument penilaian dari hasil pekerjaan siswa, dan (4) membuat jadwal penelitian.

Selain itu, siklus 1 pertemuan pertama yang dilaksanakan pada hari senin, 18 Desember 2017, peneliti menyajikan pembelajaran berbicara dengan objek "teks drama". 
peneliti juga melaksanakan siklus 1 pada pertemuan kedua yang mana pertemuan kedua tersebut dilaksanakan pada 19 Desember 2017. Pada pertemuan kedua ini, peneliti membagikan hasil memerankan drama dan mengumumkan hasil drama setiap kelompok guna untuk mengetahui kekurangankekurangannya.

a) Hasil tes siklus I

Dari hasil penelitian, peneliti menunjukkan bahwa kemampuan memerankan drama pada kelas V SD Negeri 68 Seberang Ulu 1 Palembang pada siklus 1 menunjukkan hasil cukup baik yaitu $71.07 \%$ dari 30 siswa, ada 1 siswa atau 3.33\% termasuk kategori baik sekali, 16 siswa atau 53.33\% termasuk kategori baik, dan 13 siswa atau $43.33 \%$ termasuk kategori cukup. Adapun nilai rata-rata yang baru dicapai oleh seiswa secara keseluruhan adalah $71.07 \%$.

Selain hasil tes memerankan drama, peneliti juga mendapatkan hasil dari setiap tes memerankan drama yaitu (1) pada aspek artikulasi terdapat jumlah skor sebesar 725 atau $24.17 \%$ dari 30 siswa, (2) pada aspek penyuaraan terdapat jumlah skor sebesar 794 atau $26.47 \%$ dari 30 siswa juga, dan (3) pada aspek kelancaran terdapat jumlah skor sebesar 613 atau 20.43\% dari 30 siswa dan itu juga di tunjukkan pada diagram berikut ini:

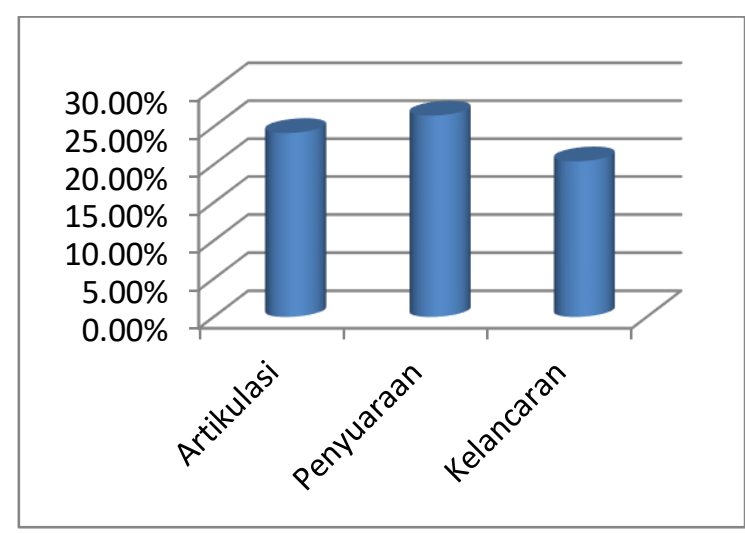

b) Hasil Observasi 
peneliti juga menyimpulkan bahwa (1) terdapat $6.66 \%$ siswa yang mampu memerankan drama $13.33 \%$ yang mampu menggunakan ekspersi, dan $13.33 \%$ yang mampu mengahayati isi cerita. (2) Terdapat 63\% siswa yang kurang mampu dalam memerankan drama, 53.33\% yang kurang menggunakan ekspresi, dan $40 \%$ yang menghayati isi cerita. (3) Terdapat $30 \%$ yang tidak mampu memerankan drama, 33.33\% yang tidak mampu menggunakan ekspresi, dan $46.66 \%$ yang tidak mampu menghayati isi cerita.

c) Refleksi Siklus I

Dari hasil data observasi (1) Terdapat sebanyak 2 siswa atau 6.66\% yang mampu memerankan drama, 19 siswa atau 63\% yang kurang mampu memerankan drama, 9 siswa atau 30\% yang tidak mampu memerankan drama. (2) Terdapat 4 siswa atau $13.33 \%$ yang mampu menggunakan ekspresi, 16 siswa atau $53.33 \%$ yang kurang mampu menggunakan ekspresi, dan 10 siswa atau $33.33 \%$ yang tidak mampu menggunakan ekspresi. (3) Terdapat 4 siswa atau $13.33 \%$ yang mampu menghayati isi cerita, 12 siswa atau $40 \%$ yang kurang mampu menghayati isi cerita, dan 14 siswa atau $46.66 \%$ yang tidak mampu menghayati isi cerita.

\section{Siklus II}

Pada siklus kedua dilaksanakan pada hari senin 15 Januari 2018 dan hari selasa 16 Januari 2018 dengan jumlah siswa 30 orang siswa dan satu teman sejawat. Sementara itu, Rencana Pelaksanaan Pembelajaran (RPP) untuk pertemuan ke-2 ini adalah seperti yang ditetapkan pada siklus pertama. Waktu yang digunakan selama 60 menit

a) Hasil tes Siklus II

Pada siklus kedua ini, peneliti menunjukkan memerankan drama pada kelas V SD Negeri 68 Seberang Ulu 1 Palembang pada siklus II menunjukkan hasil cukup baik yaitu $81.87 \%$ dari 30 siswa, ada 6 siswa atau $20 \%$ termasuk 
kategori baik sekali, 24 siswa atau $80 \%$ termasuk kategori baik. Adapun nilai ratarata yang baru dicapai oleh siswa secara keseluruhan adalah $81.87 \%$ dengan total skor 2456. Selain itu, peneliti juga menyimpulkan beberapa hasil yaitu (1) pada aspek artikulasi sebesar 861 atau $28.70 \%$ dari 30 siswa, (2) pada aspek penyuaraan sebesar 963 atau $32.10 \%$, dan (3) pada aspek kelancaran sebesar 632 atau $21.07 \%$ dari 30 siswa. Hal ini, peneliti juga menunjukkan hasilnya dalam bentuk diagram berikut

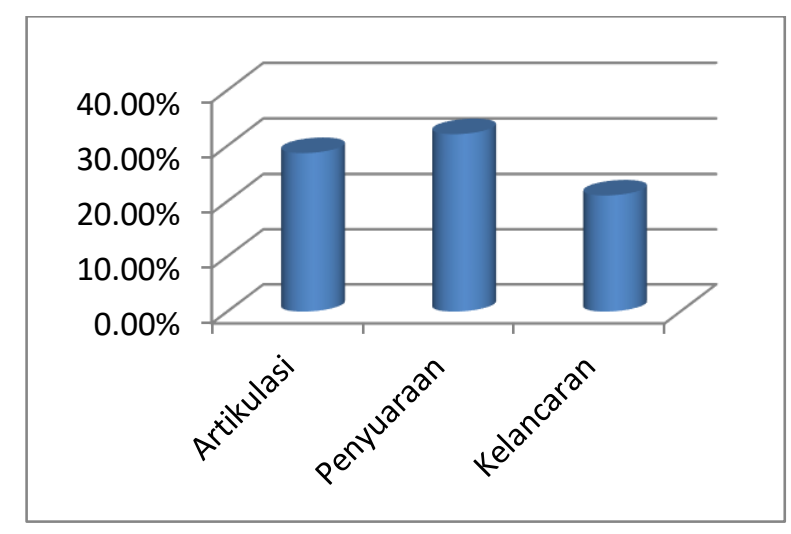

b) Hasil Observasi

peneliti menunjukkan bahwa (1) terdapat $30 \%$ siswa yang mampu memerankan drama $46.66 \%$ yang mampu menggunakan ekspersi, dan $30 \%$ yang mampu mengahayati isi cerita. (2) Terdapat 70\% siswa yang kurang mampu dalam memerankan drama, 53.33\% yang kurang menggunakan ekspresi, dan $70 \%$ yang menghayati isi cerita.

c) Refleksi

peneliti menyimpulkan bahwa (1) terdapat 9 siswa atau 70\% yang mampu memerankan drama, 14 siswa atau $46.66 \%$ yang mampu menggunakan ekspersi, dan 9 siswa atau $30 \%$ yang mampu mengahayati isi cerita. (2) Terdapat 21 siswa atau $70 \%$ siswa yang kurang mampu dalam memerankan drama, 16 siswa atau $53.33 \%$ yang kurang menggunakan ekspresi, dan 21 siswa atau $70 \%$ yang menghayati isi cerita. 


\section{SIMPULAN}

Dengan menggunakan model pembelajaran role play kriteria ketuntasan minimal (KKM) di SD Negeri 68 Seberang Ulu 1 Palembang dapat tercapai dan ini berarti kemampuan berbicara dalam memerankan drama mengalami peningkatan dan mendorong siswa lebih berani untuk berbicara dan mengekspresikan drama mereka dengan lancar. Hal ini dibuktikan dengan siklus 1 dengan nilai rata-rata 71.07\%. Dari 30 siswa, terdapat 7 siswa yang mencapai KKM atau $23.33 \%$. Selain itu terdapat juga terdapat sebanyak 2 siswa atau $6.66 \%$ yang mampu memerankan drama, 19 siswa atau 63\% yang kurang mampu memerankan drama, 9 siswa atau 30\% yang tidak mampu memerankan drama. Terdapat 4 siswa atau $13.33 \%$ yang mampu menggunakan ekspresi, 16 siswa atau $53.33 \%$ yang kurang mampu menggunakan ekspresi, dan 10 siswa atau 33.33\% yang tidak mampu menggunakan ekspresi. Terdapat 4 siswa atau $13.33 \%$ yang mampu menghayati isi cerita, 12 siswa atau 40\% yang kurang mampu menghayati isi cerita, dan 14 siswa atau $46.66 \%$ yang tidak mampu menghayati isi cerita.

Dengan menggunakan model pembelajaran role play pada siklus 2 terdapat peningkatan aktifitas siswa dalam memerankan drama yaitu dengan nilai rata-rata sebesar $81.87 \%$ atau lebih tinggi daripada siklus sebelumnya serta dengan kata lain terdapat terdapat 9 siswa atau 70\% yang mampu memerankan drama, 14 siswa atau $46.66 \%$ yang mampu menggunakan ekspersi, dan 9 siswa atau $30 \%$ yang mampu mengahayati isi cerita dan terdapat 21 siswa atau $70 \%$ siswa yang kurang mampu dalam memerankan drama, 16 siswa atau $53.33 \%$ yang kurang menggunakan ekspresi, dan 21 siswa atau $70 \%$ yang menghayati isi cerita. Selain penjelasan di atas, peneliti juga menunjukkan hasil perbandingan tersebut dalam bentuk diagram sebagai berikut: 


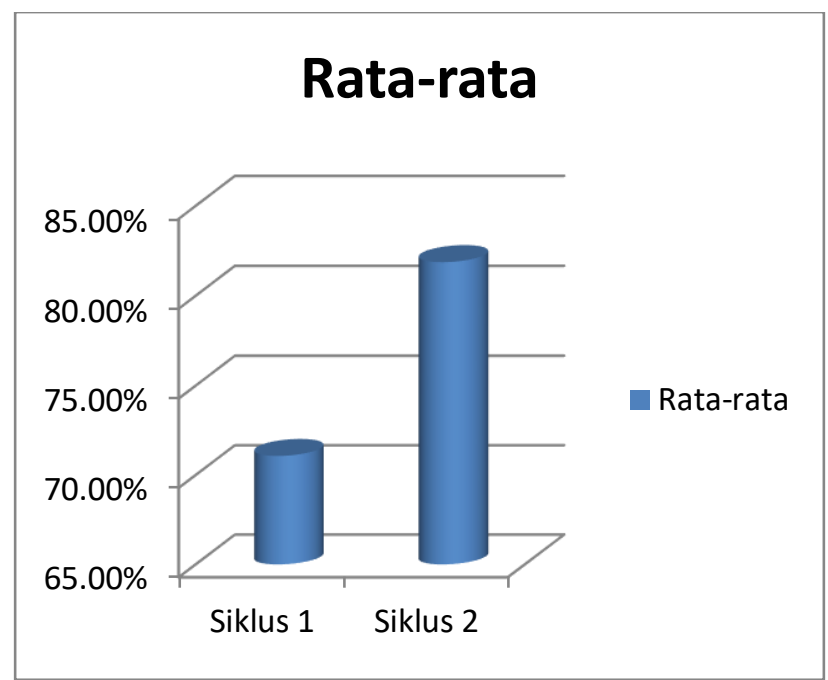

\section{DAFTAR PUSTAKA}

Arikunto, Suharsimi. 2010. Prosedur Penelitian Suatu Pendekatan Edisi Revisi V Praktik.Jakarta: Rinekacipta.

Asan, A 2007. Concept mapping in Science Class: A Study of fifth grade students. Jurnal Educational Technology \& Society, 10 (1), 186-195

Aqip, Z. 2010. Profesionalisme Guru dalam Pembelajaran. Surabaya:Insan Cendikia

Basuki T, 2000, Pembelajaran Matematika Disertai dengan Penyusunan Peta Konsep.(Tesis). Bandung: Program Pasca sarjana, Universitas Pendidikan Indonesia.

Buzan, Tony. 2012. Buku Pintar Mind Map. Jakarta: Gramedia

Dahar RW. 1996. Teori-teori Belajar, Jakarta:Erlangga.

Depdiknas. 2003. Kurikulum 2004. Pengembangan Sistem Peneilaian Hasil Belajar Berbasis Kompetensi. Jakarta: Depdiknas

Dewojati, Cahyaningrum. Drama (sejarah, teori, dan penerapannya).Yogyakarta: Javakarsa Media.

Fraenkel, Jack R. and Norman E. Wallen. 2012. How to Design and Evaluate Research in Education.New York : McGraw-Hill, Inc

Iskandar, W \& Sunendar, D. 2008. Strategi Pembelajaran Bahasa. Jakarta Rosda 
Kadir. 2004. Efektivitas strategi peta konsep dalam pembelajaran sains dan matematika. Jurnal Pendidikan dan Kebudayaan 51:10.

Kasbolah, K \& Sukaryana, I. W. 2006. Penelitian Tindakan Kelas (PTK). Malang;UM Press

Keraf, G. 1996. Eksposisi dan Deskripsi. Ende-Flores:Nusa Indah

Kosasih, E. 2012. Apresiasi Sastra Indonesia. Jakarta:Nobel Edumedia

Moeliono, A, M. 1997. Tata Bahasa Baku Bahasa Indonesia. Jakarta: Balai Pustaka

Mulyati, Y. 2009. Keterampilan Bahasa Indonesia SD. Jakarta Universitas Terbuka

Nurgiyantoro, Burhan. 2011a. Penilaian Otentik: dalam Pembelajaran Bahasa.Yogyakarta: Gadjah Mada University Press.

Nurgiantoro, B. 2001. Penelitiab dalam Pengajaran Bahasa dan Sastra. Yogyakarta:BPFE

Riantiarno, B. 2003. Menyentuh Teater. Indonesia;MU:3Books

Rosidi, I. 2009. Menulis. Yogyakarta:Kanisius

Semi, M. Atar. 2007. Dasar-Dasar Keterampilan Menulis. Bandung: Angkasa

Sugiyono. 2008. Model Penelitian Pendidikan: Pendekatan Kuantitatif,Kualitatif, dan R\&D. Bandung: Alfabeta

Suyanto. 2010. Teknik Pembelajaran Bahasa dan Sastra. Surabaya:SIC

Suyatno. 2009. Menjelajah Pembelajaran Inovatif. Sidoarjo. Masmedia Buana Pustaka

Syarif, Y.2011.Pemanfaatan Peta Konsep Untuk Meningkatkan Pemahaman Siswa tentang Indeks Hraga dan Inflasi (Tesis). Jakarta. Syarif Hidayatullah.

Tarigan, 2008. Menulis sebagai Keterampilan Berbahasa.Bandung: Angkasa

Triyanto. 2007. Model pembelajaran Kooperatif Terpadu. Jakarta: Prestasi Pustakarya

Wardarita, R. 2015. Kemampuan Menulis Karya IImiah. Palembang:Paraton 
Widura, S. 2016. Brain Management Series for Learning Strategy. Jakarta: Gramedia, Elex Media Komputindo

Willerman, M., Mac Harg, R. A. (1991). The concept map as an advance organizer. Journal of research in science teaching, vol. 28, p. 705-711

Wiyanto, A. 2002. Terampil Bermain Drama. Jakarta: Gramedia. Widiasarana. 